\title{
Potential of bacterial chitinolytic, Stenotrophomonas maltophilia, in biological control of termites
}

\author{
Faiza Jabeen ${ }^{1 *}$, Ali Hussain², Maleeha Manzoor ${ }^{1}$, Tahira Younis ${ }^{1}$, Azhar Rasul ${ }^{1}$ and Javed lqbal Qazi ${ }^{3}$
}

\begin{abstract}
Termites are important pest of crops, trees, and household wooden installments. Two species Coptotermes heimi and Heterotermes indicola are the major species of termites that results in great economic loss in Asia including Pakistan. Chitinases have drawn interest because of their relevance as biological control of pests. The study was performed to screen chitinolytic bacteria from dead termites and to determine their chitinolytic activity in degrading chitin content of termites. Ten isolates were obtained forming clear zones on chitin-containing agar plates. One isolate (JF66) had the highest $(3.3 \mathrm{~mm}$ ) chitinolytic index. Based on sequence of $16 \mathrm{~S}$ rRNA gene, the isolate was identified as Stenotrophomonas maltophilia with (99\%) similarity under Accession number KC849451 (JF66), and DNA G + C content was found to be (54.17\%). S. maltophilia (JF66) produces chitinases upto $1757.41 \mathrm{U} /$ $\mathrm{ml}$ at $30{ }^{\circ} \mathrm{C}$ and $\mathrm{pH} 6.0$ employing diammonium phosphate as a nitrogen source. Chitinase gene was also extracted and gets sequenced that confirmed its presence. Whole culture and different concentrations of crude enzyme of the isolate were tested on the chitin covering of termites. Mortalities showed that crude enzyme of isolate could degrade chitin of both species of the termites C. heimi and H. indicola. Chitinase produced by S. maltophilia had potential application as biocontrol agent for termites, but it is assumed that purification of chitinases may produce more prominent results.
\end{abstract}

Keywords: Termite, Stenotrophomonas maltophilia, Chitinases, Biological control

\section{Background}

Men have always required control measures for destructive insects like mosquitoes, bed bugs, crop pests, and many those competing with their assets such as termites. The most commonly used pest control measures are synthetic pesticides (i.e., malathion, methyl parathion, DDT, and lindane) which are the most widely used pest control measure but their frequent utilization has created a distressed ecological balance among pests resulting in resistance development in the pests as well as persistence in environment with deteriorative potential. Natural enemies are also affected when pesticides are applied hastily, which resulted in a resistant pest population, damaging crops and other products (Pohanka 2006; Thomas and Read 2007; Kumar et al. 2008). More than (99.9\%) of pesticides

\footnotetext{
* Correspondence: acancerian@hotmail.com

${ }^{1}$ Department of Zoology, Government College University Faisalabad, Punjab, Pakistan

Full list of author information is available at the end of the article
}

move into the environment rather than to the target which adversely influences public health and other valuable biota and pollutes the soil and water as well as the atmosphere (Pimentel 1995; El-Heneidy et al. 2015). The negative impact on environment and human health has educated scientist to track other substitutes. In this regard, biological control is one of the alternatives which proved to be safe and help in lowering pest density (Kumar et al. 2008 and Rakshiya et al. 2016).

Among pests, the most damaging to wood, household wooden installments, and crops are termites (Akhtar and Rashid 2001; Debelo and Degaga 2017). Pakistan is an agricultural country, and its economy depends on cash crops that are severely damaged by termite's infestation. In this region, two termite species Heterotermes and Coptotermes belong to Rhinotermitidae family are of immense economical importance. They build shelter tubes with soil, fecal material, and saliva but feed on vital plant parts and wood (Jenkins et al. 2002; Qasim et 
al. 2015). In Pakistan, especially the two termite species Coptotermes heimi and Heterotermes indicola attack wood and wooden material (Saliha et al. 2012).

Biological control has been acknowledged as more environment friendly and a safer method than reliance on chemical pesticides (Eilenberg and Hokkamen 2006; Kumar et al. 2008). In this scenario, microbial control agents are harmless as well as efficient because of their efficacy and undisruptive nature for non-target organisms (Lacey et al. 2001; Boisvert 2005). Bacterial chitinases, especially those from thermophilic bacteria showed a high potential against termites' attack in an environmentally safe manner. Chitinases are the enzymes capable of chitin hydrolysis to low molecular weight end products that are of great interest as a potential biological control agent (Huang and Chen 2004; Makino et al. 2006; Wang et al. 2006). So, chitinolytic bacteria have a great potential in controlling insects under selected conditions (Zhu et al. 2008; Osman et al. 2015). Termites like other insects bear chitin for polymerizing and strengthening their exoskeleton and other tissue/organs like trachea and gut epithelium (Merzendorfer and Zimoch 2003; Al-Sawalmih 2007). The gut of termites is indicative to design control strategy involving chitin degradation leaving insect incapable of digestion and absorption (Wiwat et al. 2000; Shternshis et al. 2002). Thus, application of bacterial chitinases for eradicating termite damages might protect humans from side effects of toxic synthetic chemicals. This is the first attempt regarding the application of bacterial chitinases in biological control of termites.

In the present study, bacterial chitinases production by Stenotrophomonas maltophilia and their termiticidal activity was quantified.

\section{Materials and methods Chitin extraction of crab}

Blue crab (Callinectes sapidus) was purchased from market and washed with water, and shells were separated. The shells were oven dried at $105{ }^{\circ} \mathrm{C}$ and crushed to powder. Chitin polymer was extracted according to the method of Rhazi et al. (2000). Finally, extracted chitin powder was dried and saved in bottles.

\section{Processing for colloidal chitin}

Chitin was processed according to the method of Jabeen and Qazi (2014). The extracted chitin in filter paper was washed several times by autoclaved distilled water till the spent wash water's $\mathrm{pH}$ became 7 . The colloidal chitin was removed from the filter paper, weighed, and stored in dark bottle at $4{ }^{\circ} \mathrm{C}$.

\section{Sampling and isolation of the chitinolytic bacterium}

Termites were sampled from trees of Quaid-e-Azam campus area, University of the Punjab, Lahore, Pakistan.
The samples were saved in tightly capped sterilized bottles and transported to laboratory for further processing. The dead termites were enriched in selective medium prepared after Furukawa et al. (1978). The medium contained $1 \%$ prepared colloidal chitin as sole carbon source; $\mathrm{NH}_{4} \mathrm{SO}_{4}, 1.0 ; \mathrm{KH}_{2} \mathrm{PO}_{4}, 0.2 ; \mathrm{K}_{2} \mathrm{HPO}_{4}, 1.6 ; \mathrm{NaCl}$, $0.1 ; \mathrm{MgSO}_{4} 7 \mathrm{H}_{2} \mathrm{O} ; \mathrm{FeSO}_{4} \cdot 7 \mathrm{H}_{2} \mathrm{O}, 0.01 ; \mathrm{CaCl}_{2} \cdot 2 \mathrm{H}_{2} \mathrm{O}, 0.02$ $(\mathrm{g} / \mathrm{L})$ dissolved in distilled water. After 5 days of incubation at $30{ }^{\circ} \mathrm{C}$ temperature, dilution was made and spread on chitin agar plates, incubated at $30{ }^{\circ} \mathrm{C}$ for 3 days. Zones of clearance appeared around colonies and then pure cultured through nutrient agar.

\section{Chitinase assay}

Chitinolytic activity of the isolate was determined by the estimation of released reducing sugars from the chitin as described by Sadafi et al. (2001). The standard curve was plotted with $\mathrm{N}$-acetylglucosamine (NAG) in the range of 100 to $600 \mu \mathrm{g} / \mathrm{ml}$. One unit of chitinolytic activity was described as $1 \mu \mathrm{mol}$ of liberation of NAG per milligram of protein per minute.

\section{Protein test}

The protein content was estimated by the method described by Bradford (1976). Bovine serum albumin (BSA) prepared from 2 to $10 \mu \mathrm{g} / \mathrm{ml}$ range with two class intervals was used as standard. Calibration curve was then plotted by performing regression analysis of $A^{595}$ absorbance versus corresponding concentrations of the standards.

\section{$16 \mathrm{~S}$ rRNA gene sequencing}

Freshly grow bacterial colony was suspended in $5 \mathrm{ml}$ sterilized nutrient broth and grown for overnight. The culture was centrifuged at 10,000 for $10 \mathrm{~min}$, and pellet was processed for DNA extraction. Bacterial 16S rRNA gene was amplified by using the universal primers $27 \mathrm{~F}\left(5^{\prime}\right.$-AGAG TTTGATCMTGGCTCAG-3') and 1492R(3'-TACG G\{Y\}TACCTTGTTACG-5') (Oligo, USA). Extraction and amplification was performed according to the method described in Jabeen and Qazi (2014). Sequencing was done from Korea and matched with the nucleotide database available at Gene Bank, using BLAST tool in NCBI (http://www.ncbi.nlm.nih.gov) for recognition of the highest percentage similarity with the described species.

\section{Phylogenetic analysis}

BLAST sequences were imported into the clustalW program package. The sequence was aligned with the closest relative and phylogenetic tree was plotted by using the neighbor joining program in clustalW package (Fig. 1). 


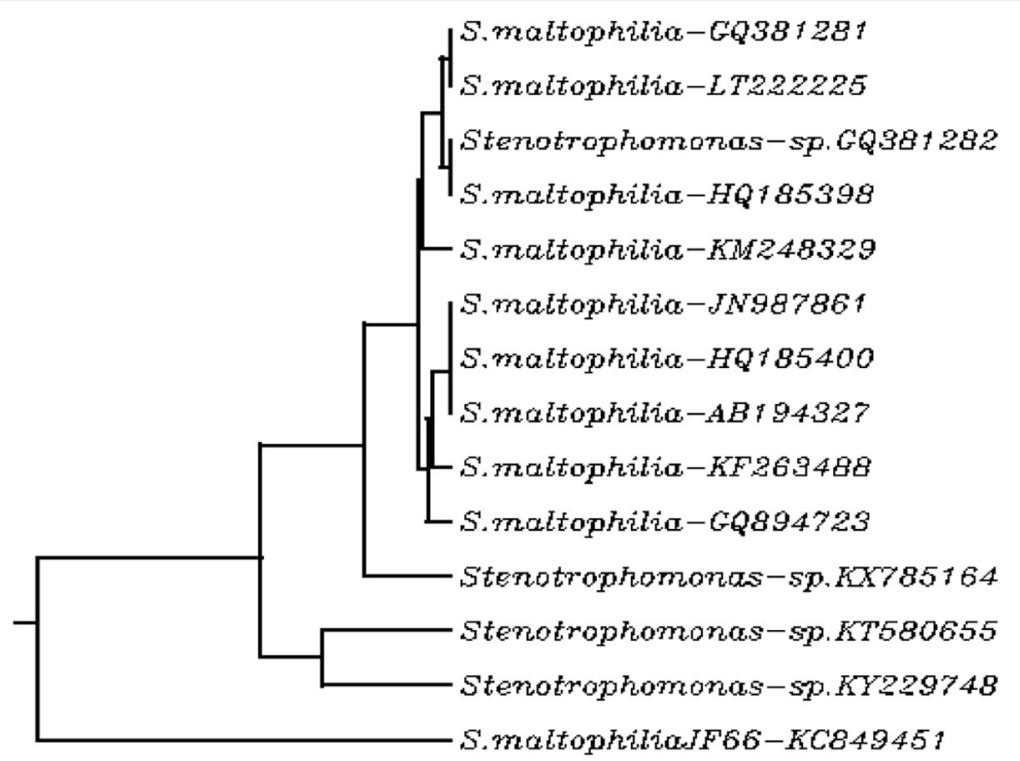

Fig. 1 Phylogenetic tree of the isolate showing highest homology with Stenotrophomonas sp. consensus neighbor-joining phylogenetic rooted tree from sequences of the $16 \mathrm{~S}$ rRNA gene, encompassing S. maltophilia

\section{Optimization of chitinase production}

Effects of temperature, $\mathrm{pH}$, and nitrogen source on chitinase production were studied by growing the isolate in chitin broth at different temperature ranging from 20 to $60{ }^{\circ} \mathrm{C}, \mathrm{pH}$ ranging from 4 to 11 for 5 days. Different nitrogen sources such as ammonium chloride, trypton, gelatin, peptone, ammonium oxalate, ammonium dihydrogen phosphate, yeast extract, and urea were supplemented to the chitin medium to study their influence on chitinase production.

\section{Enzyme characterization}

The enzyme was characterized by incubating enzyme to different $\mathrm{pH}$ levels from 4 to 11 by using different buffers acetate (4-5), phosphate (6-7), Tris $\mathrm{HCl}$ (8-9), and glycine $\mathrm{NaOH}$ buffers (10-11) similarly temperatures ranging from 20 to $60{ }^{\circ} \mathrm{C}$ for $30 \mathrm{~min}$ in shaking water bath. The crude enzyme was also incubated with different concentrations of chitin substrate at optimum $\mathrm{pH}$ and temperature for $30 \mathrm{~min}$. The enzyme activity was estimated, as described before.

\section{Amplification of chitinase gene}

The extracted DNA was also used to amplify chitinase gene(s) employing the primer sequence used by Lee et al. (2007), i.e., F(5'-AATGGGGAATTCGCAAAAGCCAGT TCTGAC-3'), and R(5'CTCTCTCTTTATC-CTCG AGTATCAAACTGAT-3') (Macrogen, Korea) using Promega Go-Taq ${ }^{\circ}$ Flexi DNA Polymerase (MGW Biotech, Germany). Following Lee et al. (2007), PCR was prepared and amplified. The gel was electrophoresed then along with $1 \mathrm{~Kb}$ plus ladder of Invitrogen ${ }^{\mathrm{TM}}$ (catalog number:
10787018) and PCR product. The PCR products were purified by using QIA quick PCR purification kit protocol, and purified product was got sequenced commercially from Macrogen, Korea.

\section{Partial purification of chitinase enzyme}

The extracellular chitinases was purified through ammonium sulphate precipitation and dialysis. Five hundred milliliter supernatant of selected strain was precipitated with ammonium sulphate at different saturation levels (20-80\%) by increasing the concentration of salt by $10 \%$ each time following the method described by Jabeen (2011). Chitinase activities and protein concentrations were measured every time during addition of salt fractions to calculate the specific activities of enzyme.

\section{Experiments on termites Collection of termites}

Termites' members of Heterotermes and Coptotermes were collected from the field and transported to the laboratory. Termites were allowed to remain within the piece of bark of tree for $24 \mathrm{~h}$. Termites were recovered and placed in a cool place $\left(28 \pm 2{ }^{\circ} \mathrm{C}\right)$ in a glass small box covered with black cloth till further use.

\section{Concentrating bacterial chitinases for termiticidal assessment}

The bacterium was grown in $50 \mathrm{ml} \mathrm{FJ} \mathrm{medium} \mathrm{at} \mathrm{their}$ corresponding enzyme optima. The growth was centrifuged in sterile centrifuge tubes, and three different concentrations were made as $1 \mathrm{X}, 5 \mathrm{X}$, and $10 \mathrm{X}$. Three test tubes were prepared with $10 \mathrm{ml}$ of supernatant in each 


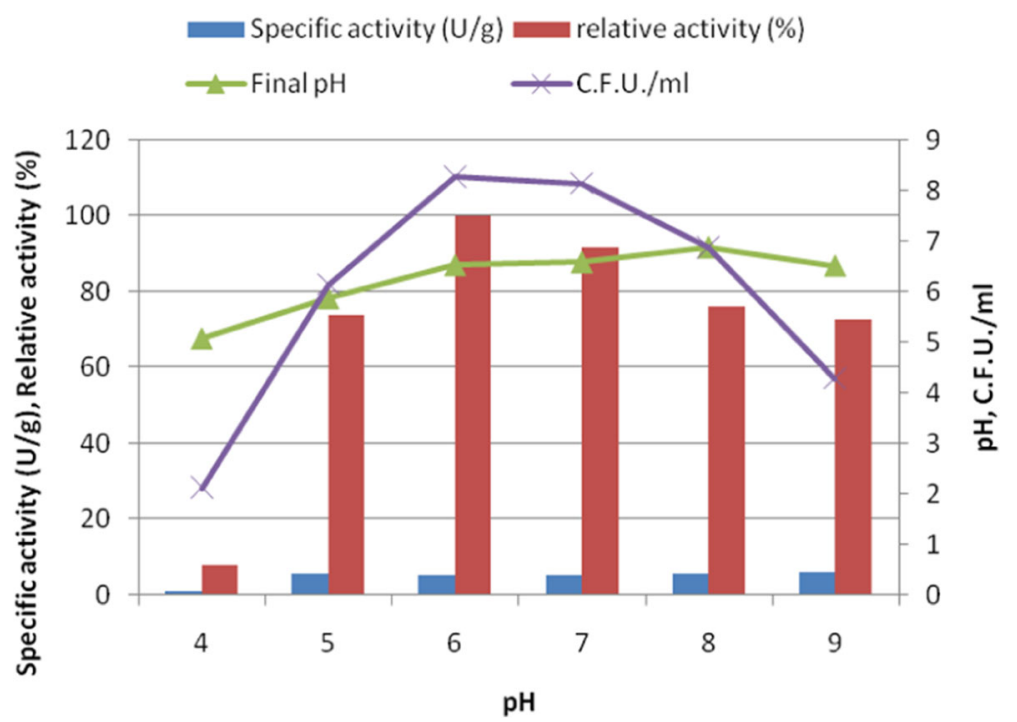

Fig. 2 Effect of pH on specific and relative activity of chitinase produced by S. maltophilia JF66 following 5 days of incubation at $37^{\circ} \mathrm{C}$ and $140 \mathrm{rpm}$

sterile capped test tube. The $10 \mathrm{ml}$ supernatant in two of the test tubes $(5 \mathrm{X}, 10 \mathrm{X})$ was dried by exposing to room temperature at sterile conditions till it becomes 5 and $1 \mathrm{ml}$ to attain $5 \mathrm{X}$ and $10 \mathrm{X}$ concentrations, respectively. A third tube was remained as it is as $1 \mathrm{X}$.

\section{Exposing termites to the bacterial isolates}

Filter paper discs of $10 \mathrm{~mm}$ were made, sterilized by autoclaving, and loaded with prepared concentrations, i.e., $1 \mathrm{X}, 5 \mathrm{X}$, and $10 \mathrm{X}$, of the bacterial culture fluids. The discs loaded with $10 \mu \mathrm{l} /$ disc of given preparation were placed in Petri plates and 10 termites free of extraneous dust etc. were exposed to them. A control was also run having filter paper discs moistened with simple sterilized distilled water. The Petri plates were covered and kept under darkness at $26 \pm 2{ }^{\circ} \mathrm{C}$ and were observed for the termite mortality after every hour up to $8 \mathrm{~h}$ and then at $24 \mathrm{~h}$ post-exposure.

\section{Preparation of bagasse made chipboard}

One gram of Sugarcane Bagasse (SCB) was sterilized in each Petri plate and was mixed with $10 \mathrm{ml}$ of a chitinolytic bacterial cell free cultural fluid. The chitinolytic chips of the SCB thus prepared were exposed to the

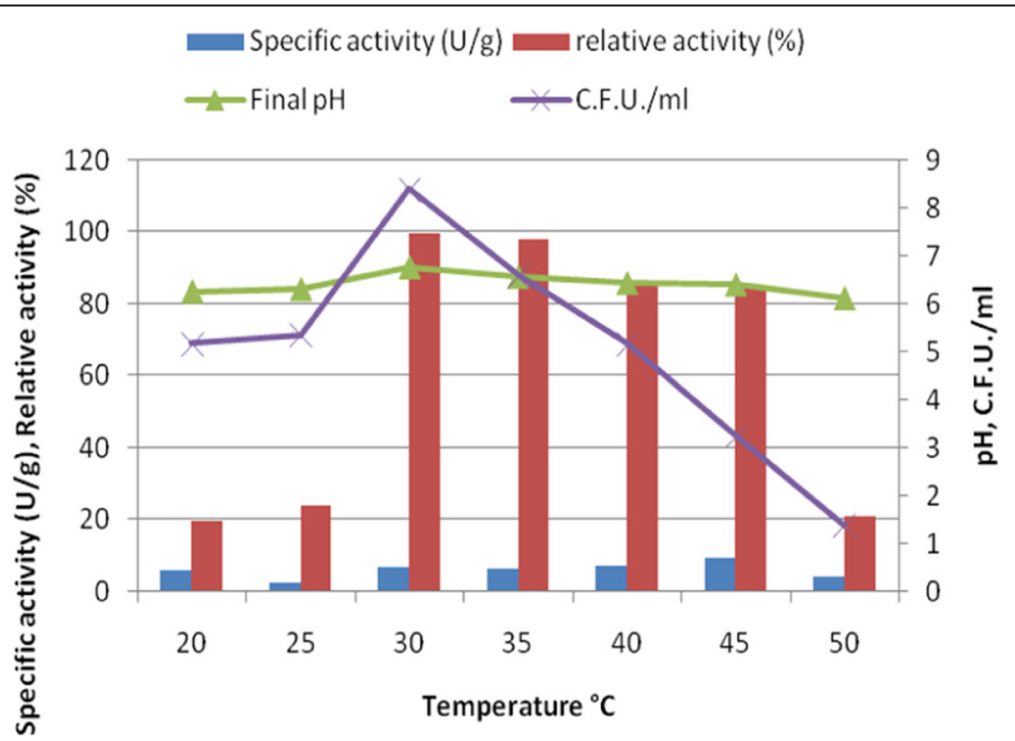

Fig. 3 Effect of different temperatures on specific and relative activities of chitinase produced by Stenotrophomonas maltophilia JF66 following 5 days of incubation at $140 \mathrm{rpm}$ 


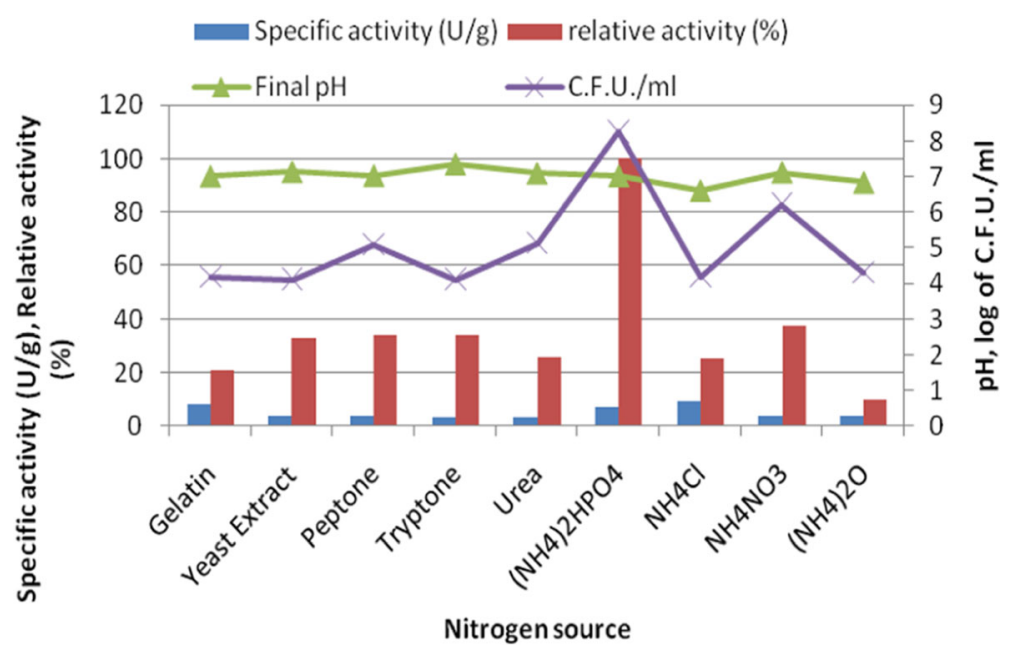

Fig. 4 Effect of different nitrogen sources on specific and relative activities of chitinase produced by S. maltophilia JF66 at optimum conditions

termites. Mortality rate of the termite was observed and recorded as mentioned before. The experiments were conducted in triplicates.

\section{Results and discussion}

\section{Processing of chitin containing waste}

Chitin was used as a sole carbon source for the production of bacterial chitinases. Edible crabs, a waste product of food industries, were chosen for the present study. The shells were processed for removal of minerals by demineralization and proteins by deproteinization. From $4.0 \mathrm{~g}$ of the dried chitin wastes $0.984 \mathrm{~g}(24.6 \%)$, chitin was obtained. Following dehydration, the figure came down to $0.55 \mathrm{~g}$ and could represent only $13.8 \%$ of the total chitin waste. This crude chitin was further processed for attaining colloidal chitin for the production of chitinases. Crude chitin was processed with concentrated hydrochloric acid. The $5.0 \mathrm{~g}$ crude chitin used for acid treatment yielded $54 \mathrm{~g}$ of colloidal chitin which was 1080\% more colloidal chitin than the crude chitin.

\section{Isolation and screening of chitinolytic bacteria}

Eighty-four bacterial strains were isolated from different samples comprising dead termites, termite affected trees, termites' mounds, termite-affected gardens, and termite-affected fields. Samples were processed on chitin containing selective agar medium. Out of the 84 isolated bacterial strains, 35 exhibited vivid zones of hydrolysis on $1.0 \%$ chitin agar medium at $\mathrm{pH}$ 6.0. The maximum ratio of $(\mathrm{ZS})$ and $(\mathrm{CS})$ to the bacterial colony size was $5.0 \mathrm{~mm}$ of the isolate JF66. This isolate was pure cultured on the selective medium intervened by culturing on nutrient agar plates. Puspita et al. (2017) found a high chitinolytic index among various bacteria including Stenotrophomonas maltophilia. The pure culture was preserved on FJ medium agar slants. Glycerol stock was also prepared employing growth in FJ broth and was

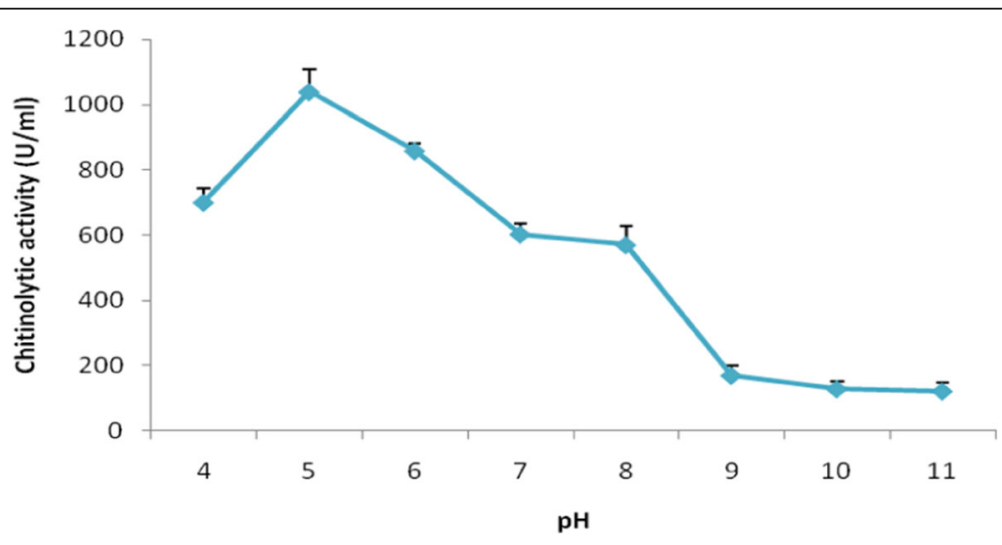

Fig. 5 Effect of different buffer pH on chitinase activity of S. maltophilia JF66, grown at optimized conditions 


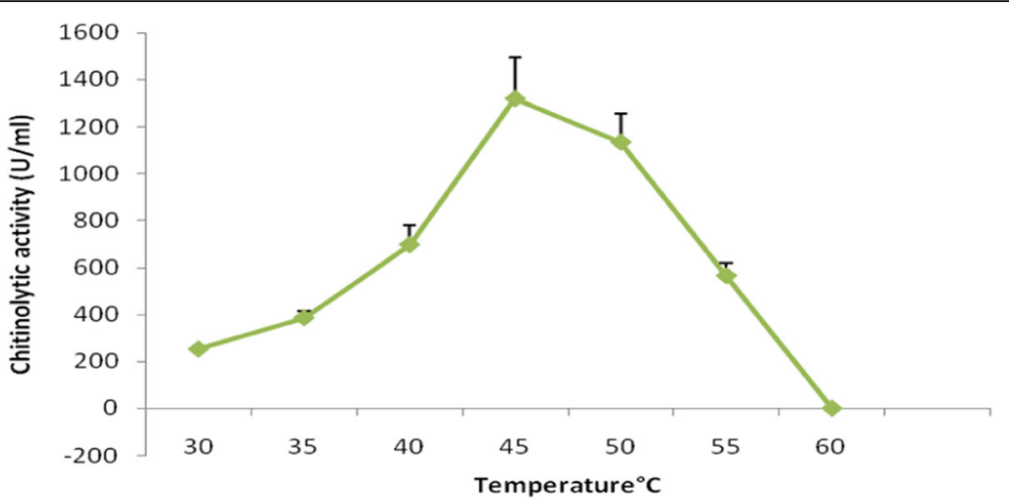

Fig. 6 Effect of incubation temperature on chitinase activity of S. maltophilia JF66, grown at optimized conditions

preserved at $-20{ }^{\circ} \mathrm{C}$. The isolate JF66 yielded maximum activity of $301.55 \mathrm{U}$ of chitinase $/ \mathrm{ml}$.

\section{Identification of isolate}

16S rRNA gene sequencing revealed the isolate as $S$. maltophilia with 99\% similarity, and their accession number obtained was KC 849451 with GC content 54.172. Alshehri et al. (2016) and Puspita et al. (2017) also identified the bacterium with the same method.

\section{Optimization of growth and chitinase production}

Maximum growth and chitinase production was recorded as $116 \times 10^{2}$ C.F.U./ml and 107.72 , respectively, at initial $\mathrm{pH}$ 6. However, significant amount of enzyme was also produced at pH 7 and could attain $(91.97 \%)$ of the level obtained at pH 6. Different $\mathrm{pH}$ profiles of chitinase produced by a variety of bacterial sources have been reported. Zarei et al. (2011) also found maximum chitinase production at $\mathrm{pH}$ employing Serratia marcescens. Narayana and Vijayalakshmiv (2009) reported similar results with Streptomyces sp. Maximum specific activity observed was $6.163 \mathrm{U} / \mathrm{g}$ at $\mathrm{pH}$ 9. The bacterial growth could approach $116 \times 10^{2}$ C.F.U./ml, following inoculation in the FJ medium with initial $\mathrm{pH} 4$. While the highest growth up to $293 \times 10^{8}$ C.F.U./ml was recorded in case of $\mathrm{pH}$ 6. Growth of the bacterium remained within the two levels mentioned (Fig. 2). By changing the temperature, $35{ }^{\circ} \mathrm{C}$ was found to be the most suitable as the chitinase activity/production rises to $512.31 \mathrm{U} / \mathrm{ml}$ while raising the temperature up to $55^{\circ} \mathrm{C}$, $78.97 \%$ reduction in yield was recorded. In Streptomyces sp. optimum temperature for chitinase activity was reported to be $35{ }^{\circ} \mathrm{C}$ by Narayana and Vijayalakshmiv (2009). At high temperature, decrease in enzyme production indicated its intolerance of elevated temperature (Fig. 3). Chitinase production is considerably increased while changing the nitrogen sources. Among various organic and inorganic nitrogen sources, diammonium hydrogen phosphate was found to the more suitable supporting enzyme yield, rise to $1757.41 \mathrm{U} / \mathrm{ml}$ releasing $0.253 \mathrm{mg} / \mathrm{ml}$ protein content. Supplementing diammonium hydrogen phosphate 3.43 -fold more chitinase

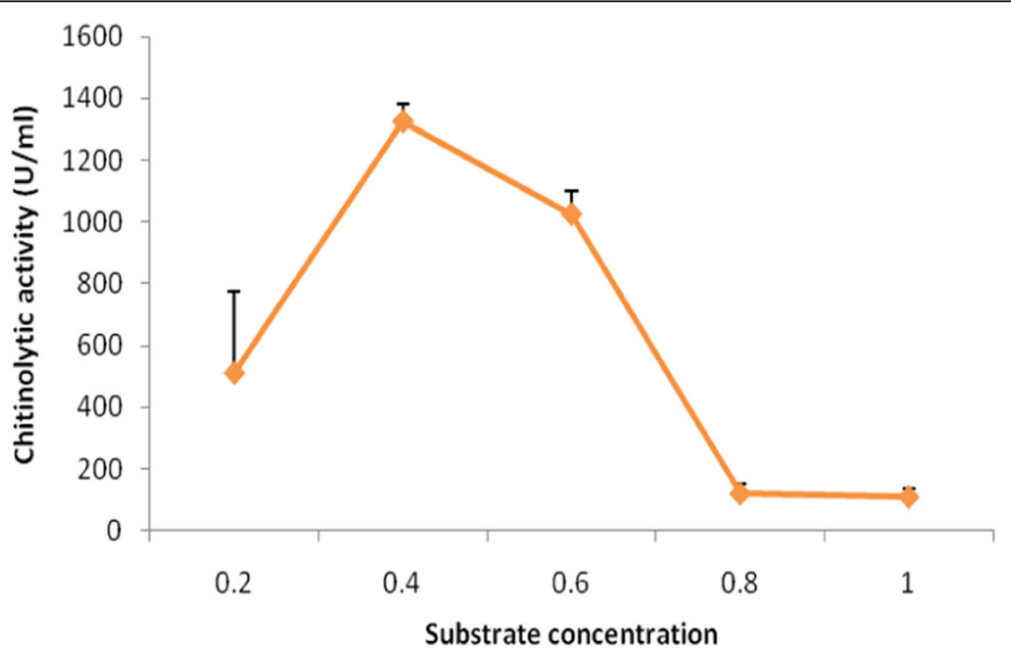

Fig. 7 Effect of substrate concentration on chitinase activity of S. maltophilia JF66, grown at optimized conditions 


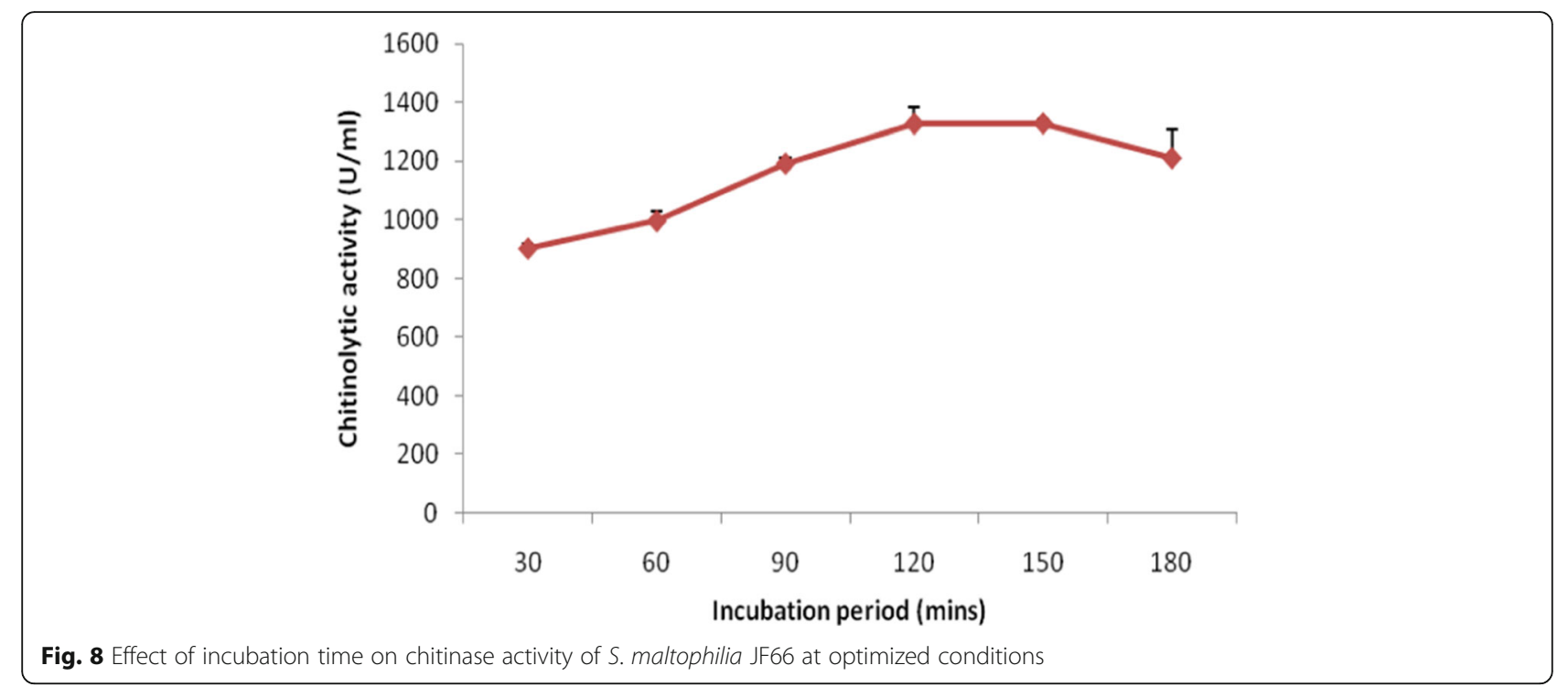

production was attained while maximum specific activity 9.367 U/g was observed with ammonium chloride. In our findings, ammonium oxide, gelatine, ammonium chloride, and urea did not support enzyme production actively (Fig. 4). Saima et al. (2013) found malt for maximum chitinase production by Aeromonas hydrophilia and A. punctata while Jha et al. (2016) reported peptone as suitable nitrogen source.

\section{Optimization and stability of chitinase activity}

From the obtained results, it can be reported that $\mathrm{pH}$ maintenance plays an important role in chitinase activity. Maximum chitinase activity was found at $\mathrm{pH} 5$ but decreased on raising the $\mathrm{pH}$ that reached null at $\mathrm{pH} 11$
(Fig. 5). Thimoteo et al. (2017) determined 5 to $7.5 \mathrm{pH}$ range optimum for chitinase activity. Temperature also affects the enzyme activity. Optimum chitinase activity observed was $1320.40 \mathrm{U} / \mathrm{ml}$ found at $45^{\circ} \mathrm{C}$. Sonel et al. (2014) also reported $45{ }^{\circ} \mathrm{C}$ temperature for the maximum stability of chitinases produced by Bacillus subtilis. The chitinase activity gradually decreases below and above this temperature. No chitinase activity was found at $60{ }^{\circ} \mathrm{C}$, which showed (100\%) decrease from optimum chitinase activity (Fig. 6). Different concentration of colloidal chitin was checked to conclude the best concentration for highest chitinase production that can be used at large scale. The enzyme activity increased to $1327.25 \mathrm{U} / \mathrm{ml}$ by applying $0.4 \%$ substrate concentration

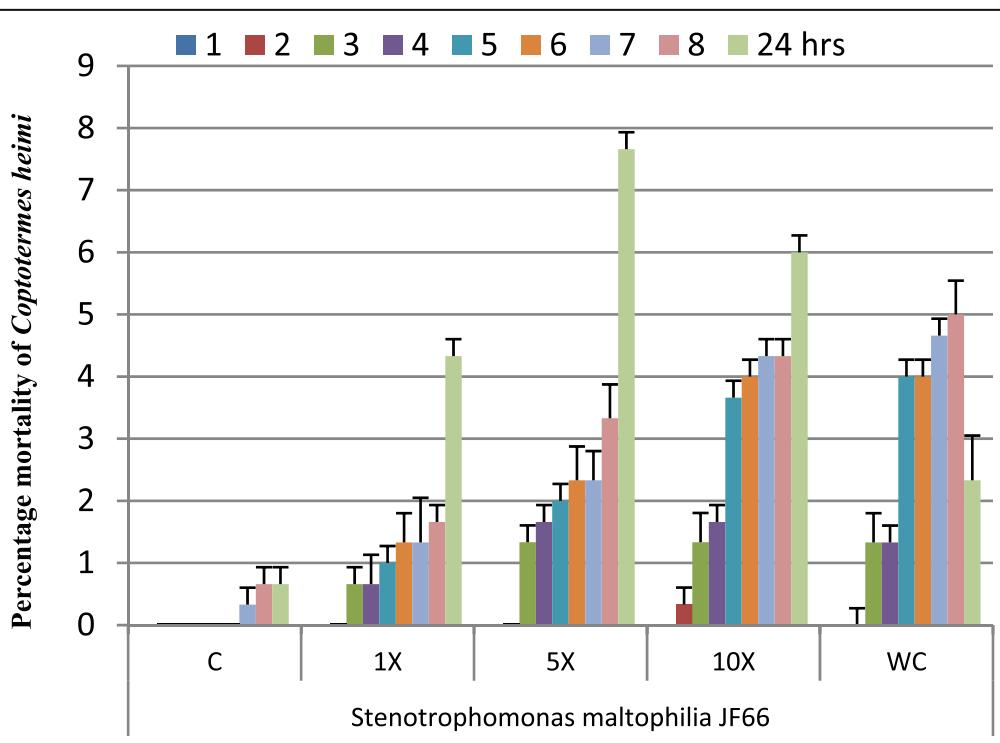

Fig. 9 Percentage mortality of Coptotermes heimi exposed to the cultures (WC) and cell-free culture fluids of varying strength of S. maltophilia JF66 


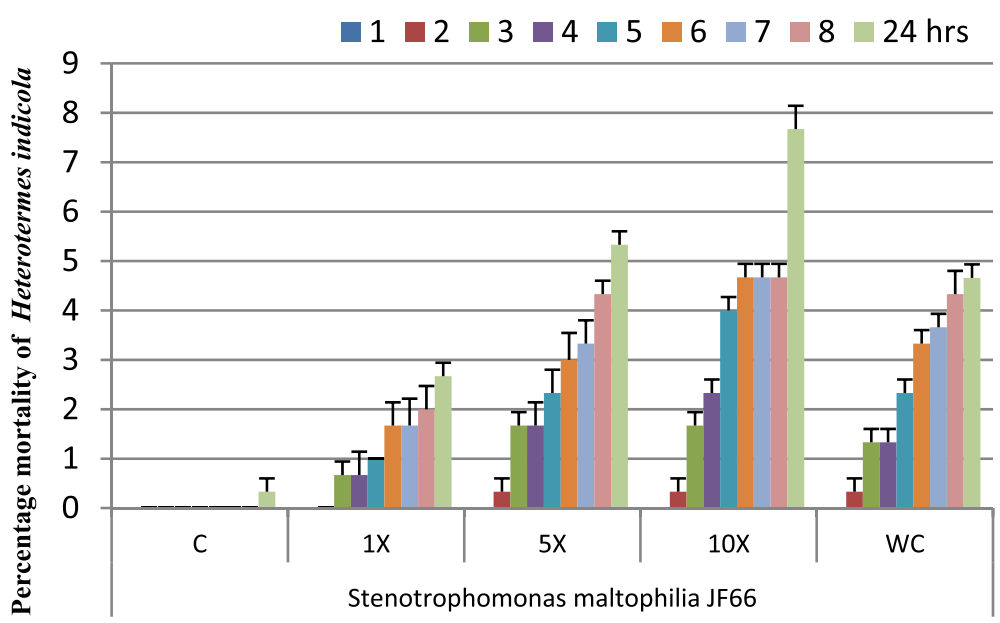

Fig. 10 Percentage mortality of Heterotermes indicola exposed to the cultures (WC) and cell-free culture fluids of varying strength of Stenotrophomonas maltophilia JF66

while decreased on adding more substrate and found to be reached $111.69 \mathrm{U} / \mathrm{ml}$ at $1.0 \%$ substrate which was 91.58\% less than optimum chitinase activity (Fig. 7). Ajayi et al. (2015) reported $0.15 \%$ most suitable for two Bacillus species to produce maximum chitinase activity. Obtained results are near to findings of Karunya et al. (2011) who found $0.3 \%$ colloidal chitin for the maximum growth. Further chitinase activity was improved by increasing the incubation time that get higher by incubating the enzyme-substrate complex at $150 \mathrm{~min}$ (Fig. 8). Shirazi et al. (2007) revealed that considerable chitinase activity was found while increasing incubation time to $120 \mathrm{~min}$.

\section{Extraction of chitinase gene}

The amplified chitinase gene showed about 1.7-kb distinct band. The purified amplicon was got sequenced commercially from Korea. Lee et al. (2007) isolated the chitinase gene from Bacillus sp. using the same primers and conditions.

\section{Termiticidal effects of the bacterial cultures and their cell-} free cultural fluids

The experiments were performed on two termite species, i.e., Coptotermes heimi and Heterotermes indicola. These species are threat in Punjab (Pakistan) for destruction of house hold wooden structures. Qureshi et al. (2014) also worked on the same species to control the termites by using antiflagellates drugs for protozoan living in termites. In this regard, Bacillus thuringienesis was reported as insecticidal against many pest including termites by many workers.

This is the first report on effectiveness of bacterial chitinases on termites species frequently found in Pakistan destroying wood and crops. The termiticidal activity was a function of the bacterial chitinases, as the highest mortalities up to $73 \%$ was recorded for $10 \mathrm{X}$ cell-free cultural fluids of $S$. maltophilia JF66 within $24 \mathrm{~h}$ of exposure in case of Coptotermes heimi (Fig. 9). Approaching levels of mortality was recorded for the whole S. maltophilia JF66. These observations are tempting to provoke into the bacterial viability following the cultural ingestion in the termites' gut. In case of Heterotermes indicola upto $77 \%$ mortalities was found within $24 \mathrm{~h}$ of exposure. Whole culture of S. maltophilia JF66 could cause only $47 \%$ mortality (Fig. 10). Husen et al. (2015) worked on Pentoxifylline that enhanced the chitinolytic activity to check termiticidal effect and inhibited the growth of termites.

It was found that more concentrated enzyme caused high termite mortality. Ten times cell-free cultural fluid (containing chitinases) exhibited the highest termite mortality. The whole culture also proved to be termiticidal in general.

Termiticidal effects of the bacterial cell-free cultural fluids with $10 \%$ sugarcane bagasse preparation

The highest mortality of 53\% was obtained for the Coptotermes heimi by the S. maltophilia JF66 in contrast to $3.3 \%$ deaths of control animals, following $24 \mathrm{~h}$ of the exposure. More or less comparable results were obtained for Heterotermes indicola, where S. maltophilia JF66 caused $57 \%$ deaths following $24 \mathrm{~h}$ of exposure, in contrast to $6.7 \%$ deaths of the control animals. Different microbes were used with varying formulation by many authors without using sugarcane bagasse. Wright and Cornelius (2012) found $72.5 \%$ mortality of Coptotermes formosanus by applying entopathogenic fungi Isaria fumosorosea at $10^{8}$ spores $/ \mathrm{ml}$ on day 7. Similarly Devi et al. (2007) also revealed that $100 \%$ mortality of termite 
species Odontotermes obesus was achieved by using Rhizobacterial isolates $R$. radiobacter and Al. latus following 1-h incubation. Treatment indicated that the strategy hypothesized for controlling the termite's damage of indoor artificial wooden structure need further attention of the researchers for materializing the application of the biological control.

\section{Conclusion}

Findings of this work showed that chitin can be extracted from edible crab shell chemically and further purification made it potent carbon and nitrogen source for isolation of chitinolytic bacteria. S. maltophilia produced chitinases by utilizing extracted crab chitin. Production of chitinases by $S$. maltophilia increased when their conditions were optimized. Presence of chitinase gene confirmed its chitinolytic activity. Percentage mortality employing chitinases to control the termites proved that chitinolytic S. maltophilia is an effective biological control agent of some insect pests. Further purification of chitinases and optimization of other supporting factors may improve the enzyme activity and mortality rate of termites.

\section{Acknowledgements}

I would like to thank my all colleagues who participated in this project.

\section{Funding}

Higher Education commission (HEC) of Pakistan funded the whole project.

\section{Availability of data and materials}

The authors declare that they have no objection to the availability of data and materials.

\section{Authors' contributions}

Faiza Jabeen performed the experiments. Ali Hussain helped in statistical analysis. Maleeha Manzoor and Tahira Younis collected the samples. Azhar Rasul worked on collecting and arranging the data. Javed labal Qazi supervised and facilitated the whole project. All authors read and approved the final manuscript.

\section{Ethics approval and consent to participate}

Not applicable.

\section{Consent for publication}

All authors are willing for publications.

\section{Competing interests}

The authors declare that they have no competing of interests.

\section{Publisher's Note}

Springer Nature remains neutral with regard to jurisdictional claims in published maps and institutional affiliations.

\section{Author details}

'Department of Zoology, Government College University Faisalabad, Punjab, Pakistan. ${ }^{2}$ Department of wild life and ecology, University of veterinary and animal sciences, Lahore, Pakistan. ${ }^{3}$ Department of Zoology, University of the Punjab Lahore, Punjab, Pakistan.
Received: 2 July 2018 Accepted: 25 October 2018

Published online: 07 November 2018

\section{References}

Ajayi AA, Onibokun EA, Adedeji OM, George FOA (2015) Characterization of chitinase from the African catfish, Clarias gariepinus (BURCHELL, 1822). International journal of advances in science. Eng Technol 3:88-95

Akhtar MS, Rashid MI (2001) Studies on population density and diversity of termites of district Bahawalnagar. Journal of Research (Science) 12:116-122

Al-Sawalmih A (2007) Crystallographic texture of the arthropod cuticle using synchrotron wide angle X-ray diffraction. Ph.D, thesis Max-Planck Institute of Iron research place Dusseldorf Germany pp 39

Alshehri WA, Elhamshary OI, Alqourashy NH, Ahmad SE (2016) Identification and characterization of chitinolytic strains of Stenotrophomonas maltophilia, isolated from Mentha and ocimum plants Saudi Arabia. International Journal of Scientific Research 51:405-407

Boisvert M (2005) Utilization of Bacillus thuringiensis var.israelensis (Bti)-based formulation for the biological control of mosquitoes in Canada. In: 6th Pacific Rim Conference on the Biotechnology of Bacillus thuringiensis and its environmental impact (Coe, J.C., Otvos, I.S., Schwartz, J.L. and Vincent, C. eds. ), Victoria $\mathrm{BC}$

Bradford MM (1976) A rapid and sensitive method for the quantitation of microgram quantities of protein utilizing the principle of protein-dye binding. Anal Biochem 72:248-254

Debelo DG, Degaga EG (2017) Study on termite damage to different species of tree seedlings in the central Rift Valley of Ethiopia. African Journal of Agricultutral Research 12:161-168

Devi KK, Seth N, Kothamasi S, Kothamasi D (2007) Hydrogen cyanide-producing Rhizobacteria kill subterranean termite Odontotermes obesus (Rambur) by cyanide poisoning under In Vitro conditions. Curr Microbiol 54:74-78

Eilenberg J, Hokkamen HMT (2006) In: an ecological and societal approach to biological control. Springer. Drodrecht, The Netherlands, pp 1-11

El-Heneidy AH, Khidr AA, Taman AA (2015) Side-effects of insecticides on nontarget organisms: 1-in Egyptian cotton fields. Egyptian Journal of Biological Pest Control 15:685-690

Furukawa K, Matsumura F, Tonomura K (1978) Alcaligenes and Acinetobacter strain capable of degrading polychlorinated biphenyls. Agric Biol Chem 42: 543-548

Huang CJ, Chen CY (2004) Gene cloning and biochemical characterization of chitinase CH from Bacillus cereus 28-9. Annals in Microbiology 54:289-297

Husen TJ, Kamble ST, Stone JM (2015) Effect of pentoxifylline on chitinolytic enzyme activity in the Eastern subterranean termite (Isoptera: Rhinotermitidae). J Entomol Sci 50:295-310

Jabeen F (2011) Potential of thermohilic chitinolytic bacteria for making termite resistant chipboard. PhD thesis. University of the Punjab, Lahore, Pakistan

Jabeen F, Qazi JI (2014) Isolation of chitinase yielding Bacillus cereus JF68 from soil employing an edible crab shell chitin. J Sci Ind Res 73:771-776

Jenkins TM, Dean RE, Foschler BT (2002) DNA technology, interstate commerce, and the likely origin of Formosans subterranean termite (Isoptea: Rhinotermitidae) infestation in Atlanta, Georgia. J Econ Entomol 95:381-389

Jha S, Modi HA, Jha CK (2016) Characterization of extracellular chitinase produced from Streptomyces rubiginosus isolated from rhizosphere of Gossypium sp. Cogent Food and Agriculture 2:119-225

Kavi Karunya S, Reetha D, Saranraj P, Johnmilton D (2011) Optimization and purification of chitinase produced by Bacillus subtilis and its antifungal activity against plant pathogens. International Journal of Pharmaceutical and Biological Archives 2:680-1685

Kumar S, Chandra A, Pandey KC (2008) Bacillus thuringiensis transgenic crop: an environment friendly insect-pest management strategy. J Environ Biol 29 641-653

Lacey LA, Frutos R, Kaya HK, Vail P (2001) Insect pathogens as biological control agents: do they have a future? Biol Control 21:230-248

Lee Y, Park I, Yoo J, Chung S, Lee Y, Cho Y, Ahn S, Kim C, Choi Y (2007) Cloning, purification and characterization of chitinase from Bacillus sp. DAU101. Bioresour Technol 98:2734-2741

Makino A, Kurosaki K, Ohmae M, Kobayashi S (2006) Chitinase-catalyzed synthesis of alternatingly $\mathrm{N}$-deacetylated chitin: a chitin-chitiosan hybrid polysaccharide. Biomacromolecules 7:950-957

Meszendorfer H, Zimoch L (2003) Chitin metabolism in insects: structure, function and regulation of chitin synthases and chitinases. J Exp Biol 206:4393-4412 
Narayana KJP, Vijayalakshmi M (2009) Chitinase production by streptomyces sp. anu 6277. Brazilian Journal of Microbiology (2009) 40:725-733

Osman GH, Assem SK, Alreedy RM, El-Ghareeb DK, Barry MA, Rastogi A, Kalaji HM (2015) Development of insect resistant maize plants expressing a chitinase gene from the cotton leaf worm, Spodoptera littoralis. Scientific Report 5:18067

Pimentel D (1995) Amounts of pesticides reaching target pests: environmental impacts and ethics. Journal of Agriculture and Environmental Ethics 8:17-29

Pohanka A (2006) Antifungal antibiotics from potential biocontrol microorganisms. PhD. Thesis, faculty of natural resources and agricultural sciences department of chemistry, Swedish University of Agricultural Sciences, pp 72. In: Uppsala

Puspita ID, Wardani A, Puspitasari RROA, Nugraheni PS, Putra MGS, Pudjiraharti S, Ustadi (2017) Occurence of chitinolytic bacteria in shrimp rusip and measurement of their chitin degrading enzyme activities. Biodiversitas 18 1275-1281

Qasim M, Lin Y, Fang D (2015) Termites and microbial biological control strategies. South Asia Journal of Multidisciplinary Studies 1:1-27

Qureshi NA, Qureshi MZ, Ullah A (2014) The effect of some Protozoacides, on the survival of symbiotic flagellates of Coptotermes heimi and Heterotermes indicola. International Journal of Sciences: Basic and Applied Research 15: 386-396

Rakshiya YS, Verma MK, Sindhu SS (2016) Efficacy of antagonistic soil bacteria in management of subterranean termites (Isoptera). Research in Environment and Life Sciences 9:949-955

Rhazi M, Desbrières J, Tolaimate A, Alagui A, Vottero P (2000) Investigation of different natural sources of chitin: influence of the source and deacetylation process on the physicochemical characteristics of chitosan. Polym Int 49: $337-344$

Sadafi N, Cherif M, Fliss I, Boudabbous A, Antoun H (2001) Evaluation of Bacillus isolates from salty soil and Bacillus thuringiensis strain for the biocontrol of fusarium dry rot of potato tubers. J Plant Pathol 83:101-118

Saima KM, Roohi AIZ (2013) Isolation of novel chitinolytic bacteria and production optimization of extracellular chitinase. Journal of Genetic Engineering and Biotechnology 11:39-46

Saliha Z, Sattar A, Farid A, Shakoori AR (2012) Termites of Pakistan \& their control. Zoological Society of Pakistan, p 102

Senol M, Nadaroglu H, Dikbas N, Kotan R (2014) Purification of Chitinase enzymes from Bacillus subtilis bacteria TV-125, investigation of kinetic properties and antifungal activity against Fusarium culmorum. Ann Clin Microbiol Antimicrob 13:35

Shirazi F, Kulkarni M, Deshpande MV (2007) A rapid and sensitive method for screening of chitinase inhibitors using Ostazin brilliant red labelled chitin as a substrate for chitinase assay. Lett Appl Microbiol 44:660-665

Shternshis MV, Ovchinnikova LA, Duzhak AB, Tomilova OG (2002) The efficiency of viral and bacterial entomopathogens formulated with chitinase for biocontrol of lepidopteran cabbage pests. Arch Phytopathol Plant Protect 35 $161-169$

Thimoteo SS, Glogauer A, Faoro H, Thimoteo SS, Glogauer A, Faoro H, de Souza EM, Huergo LF, Moerschbacher BM, Pedrosa FO (2017) a broad pH range and processive chitinase from a metagenome library. Braz J Med Biol Res 2017: 50(1):e5658

Thomas MB, Read AF (2007) Can biopesticides control malaria? Nature Review 5: 377-383

Wang SL, Lin TY, Yen YH, Liao HF, Chen YJ (2006) Bioconversion of shellfish chitin wastes for the production of Bacillus subtilis W-118 chitinase. Carbohydr Res 341:2507-2515

Wiwat C, Thaithanun S, Pantuwatana S, Bhumiratana A (2000) Toxicity of chitinase-producing Bacillus thuringiensis ssp. Kurstaki HD-1 (G) toward Plutella xylostella. J Invertebr Pathol 76:270-277

Wright MS, Cornelius ML (2012) Mortality and repellent effects of microbial pathogens on Coptotermes formosanus (Isoptera: Rhinotermitidae). BMC Microbiol 12:291

Zarei M, Aminzadeh S, Zolgharnein H, Safahieh A, Daliri M, Noghabi KA, Ghoroghi A, Motallebi A (2011) Characterization of a chitinase with antifungal activity from a native Serratia marcescens B4A. Brazilian Journal of Micrbiology 42(3): 1017-1029

Zhu Y, Pan J, Qiu J, Guan X (2008) Isolation and characterization of a chitinase gene from entamopathogenic fungus Verticillium leca. Braz J Microbiol 39 $314-320$

\section{Submit your manuscript to a SpringerOpen ${ }^{\circ}$ journal and benefit from:}

- Convenient online submission

- Rigorous peer review

- Open access: articles freely available online

- High visibility within the field

- Retaining the copyright to your article

Submit your next manuscript at $\boldsymbol{\nabla}$ springeropen.com 